\title{
THE SIGNIFICANCE OF THE BATTLE FOR CUITO CUANAVALE: LONG-TERM FORESIGHT OF THE CURRENT STRATEGIC LANDSCAPE
}

\section{Andreas Velthuizen, Independent Researcher}

They talked about who won and who lost. Human reason won. Mankind won.

Nikita Khrushchev (1894-1971)

\begin{abstract}
This article deals with the long-term outcomes of the Battle of Cuito Cuanavale in Angola (1987-1988) and the effect of the outcomes on the current strategic landscape in Southern Africa. The crux of the article is to learn about the value of long-term foresight for strategising in an international context. After a short discussion of the research methodology, the desired long-term outcomes, as perceived by the major roleplayers before the battle, will be described and explained. For the purpose of elucidation, a description is included of the events preceding the battle and the course of the battle itself. Finally, the long-term outcomes within the context of the current strategic landscape in Southern Africa will be described and explained. The article concludes with recommendations on the value of long-term strategic foresight and the importance to maintain strategic instruments, including military force, to ensure that the foreseen outcomes become reality.
\end{abstract}

\section{Introduction}

During the December 2007 ANC conference in Polokwane, it was declared that:

...the 20th anniversary of the defeat of the SADF at the battle of Cuito Cuanavale, which marked a turning point in the apartheid war of aggression against the people of Angola, contributing to the achievement of Namibian independence, and providing impetus to the process that led to the negotiated end of apartheid. We use this 


\section{8}

occasion to salute the sons and daughters of the Cuban people who laid down their lives in the fight for our freedom (ANC 2008).

This declaration implies clearly the achievement of long-term outcomes as seen from an anti-apartheid perspective, with the battle for Cuito Cuanavale as a main event that contributed to such achievement.

The question that arises is whether the long-term outcomes that eventually changed the strategic landscape in Southern Africa could have been foreseen before the battle commenced. The aim of this article is therefore to describe and explain how the anticipated outcomes of the battle of Cuito Cuanavale in 1988 manifested in the longterm strategic landscape in Southern Africa more than twenty years later. The crux of the article will be to learn about the value of long-term foresight for strategising in an international context.

After a short discussion of the research methodology, the desired long-term outcomes as seen by the major role-players before the battle, will be described and explained. Furthermore, the events preceding the battle and the course of the battle will be described, followed by the long-term outcomes which will be described and explained within the current strategic landscape in Southern Africa.

\section{Research methodology}

The initial research on this theme from 1990 to 1994 covered mainly content analyses of all available literature, including classified literature under control of the South African Defence Force (SADF), and semi-structured interviews with participants to verify facts. Participants included several South African general officers and Dr Vladimir Lebedev, a political advisor from the former Soviet Union in Angola. Access by the author to vital material from the South African Department of Foreign Affairs was refused because of the "sensitive nature" of the information. Documentation from Angola was not available because military relations were not yet normalised at that stage. Soviet and Cuban archives could not be accessed for practical and cost reasons. The absence of this material was partially compensated for by using personal interviews with Angolan officers visiting South Africa to verify some facts and limited publications of the viewpoints of major decision-makers such as President Fidel Castro. During this time, the professional official documentation kept by the SADF had been found of important historical value. The only contradictions to the primary data kept in the current South African National Defence Force (SANDF) archives, were those from non-participants in possession of secondary information and that which showed the tendency to distort interpretations for propaganda purposes.

Today the researcher enjoys the privilege of some newly published material and direct access to participants who fought with Angola during the battle of Cuito 
Cuanavale. The work of Vladimir Shubin, Piero Gleijesis and some interpretations by former Minister Kasrils, especially, added value and covered the gaps in the initial research. Literature from obvious propagandistic nature was avoided, while ample available literature of good academic and professional quality assisted in reaching credible conclusions.

The author participated in the SADF involvement in Angola and Namibia from subunit level since 1976 and served on the staff of the Chief of the SADF during the Battle for Cuito Cuanavale. Although this personal exposure poses the underlying danger of being biased towards old masters or showing pitfalls of political correctness to satisfy current popular interpretations, special care was taken to ensure that personal experience was only used to improve insight into events. Eventually this awareness contributed to the maintenance of academic standards.

Cuba, the South African government during the 1980s, the South African Defence Force (SADF), UNITA and the Armed forces of Angola (FAPLA), Cuba and the Soviet Union served as units of analysis. The level of analysis is military strategic, with operational aspects mentioned only to elucidate the strategic scenario.

\section{The desired long-term outcomes in 1987}

The major role-players involved in the conflict in Angola envisaged the long-term outcomes of the conflict, of which the Battle for Cuito Cuanavale formed part, differently. However, the main regional role players, namely South Africa, Angola and the South West African People's Organisation (SWAPO) had a very clear foresight of what should be achieved.

On 17 July 1985, State President P.W. Botha committed himself to the internationally accepted independence of Namibia in a spirit of freedom, fairness, and security. On 3 March 1986, he declared South Africa willing to implement United Nations (UN) Resolution 435 by 1 August 1986 if a "firm and satisfactory agreement" could be reached on Cuban troop withdrawal (RSA, House of Assembly 1988).

SWAPO and its allies still called for the unconditional and immediate implementation of Resolution 435 because they knew that they would probably win an election. The implementation of Resolution 435 depended mainly on the willingness of the South African government to co-operate, but the South African government and most of the internal parties in Namibia used the presence of the Cubans in Angola and UN partiality against SWAPO to delay the process. By 1987, the South African government was no longer in favour of UN Resolution 435 but was bound by the commitments of former governments to accept it and the government realised that there were no alternatives to the resolution (Du Plessis 1988). 
In his speech to the Joint Assembly of Parliament on 24 August 1988, a year after the first conventional units of the SADF entered Angola, President Botha confirmed that the goal of the South African government was the establishment of a democratic multiparty government in Windhoek. Such a government had to be acceptable to the international community, while the security forces had to ensure an election without external military intervention. President Botha confirmed that the goal sought by the South African government was the independence of Namibia under a legitimate government in a secure environment. Linking two issues, the independence of Namibia and the complete withdrawal of the Cuban military contingent were the ideal circumstances aspired to (RSA, House of Assembly 1988).

According to Shubin (2008:102), during tripartite Soviet-Angolan-Cuban consultations in Moscow in January 1985, it was decided to strengthen the defence capacity, independence, and territorial integrity of Angola. However, in February 1986, at the $26^{\text {th }}$ Congress of the CPSU (Communist Party of the Soviet Union), President Mikhail Gorbachev emphasised the need for regional conflicts to be settled politically, followed by lively diplomatic activity to achieve that (Shubin 2008:113). According to Crocker (1992:336) he was approached by the Soviet Union for the collective solving of regional conflict situations, but he remained suspicious of the intentions of the Soviet Union.

By 1987, "new thinking" of the Soviet Union formed the basis of super power cooperation. The most important elements of this new thinking were drastic measures to curtail the arms race, the replacement of confrontation with international co-operation, and the resolution that decisions had to be taken bearing in mind the interests of all actors involved in a conflict. Soviet actions also show evidence of recognition of the importance of local factors as causes of such conflicts, and an attempt to address these without endangering either the Soviet Union's own position or that of its clients. This led to some encouraging concessions on the part of the Soviet Union and its allies, jointly or separately. The resolution of conflicts, such as those in Angola, became possible because of Soviet flexibility. Support to national liberation movements, however, was still the official Soviet policy (McFarlane \& Nel 1989:1).

In this regard, Shubin (2008:105) explains the Angolan offensive of 1987 in terms of the support for UNITA (and in practice the SADF) by Washington. Against the background of the repeal of the Clark Amendment (which banned support for UNITA) by US Congress in 1985, a formal visit by Jonas Savimbi to President Reagan (January 1986) and the sinking of two Soviet vessels by South African Special Forces in the Angolan harbour of Namibe during June 1986 (See Map 1), the new Angolan offensive culminated in the Battle of Cuito Cuanavale. 


\section{1}

In a speech on Radio Havana on 12 December 1988, Castro denied Cuban participation in the initial FAPLA offensive and said that the FAPLA offensive of 1987 created a crisis for Cuba. He explained that south-eastern Angola was very far from the Cuban frontline and Cubans were not participating in the offensive, and "Those who wanted the operation and those in favour of the operation were advised by Cuba that the offensive could not be carried out if appropriate conditions to stop South Africa from intervening could not be created." However, other allies ignored the Cuban point of view.

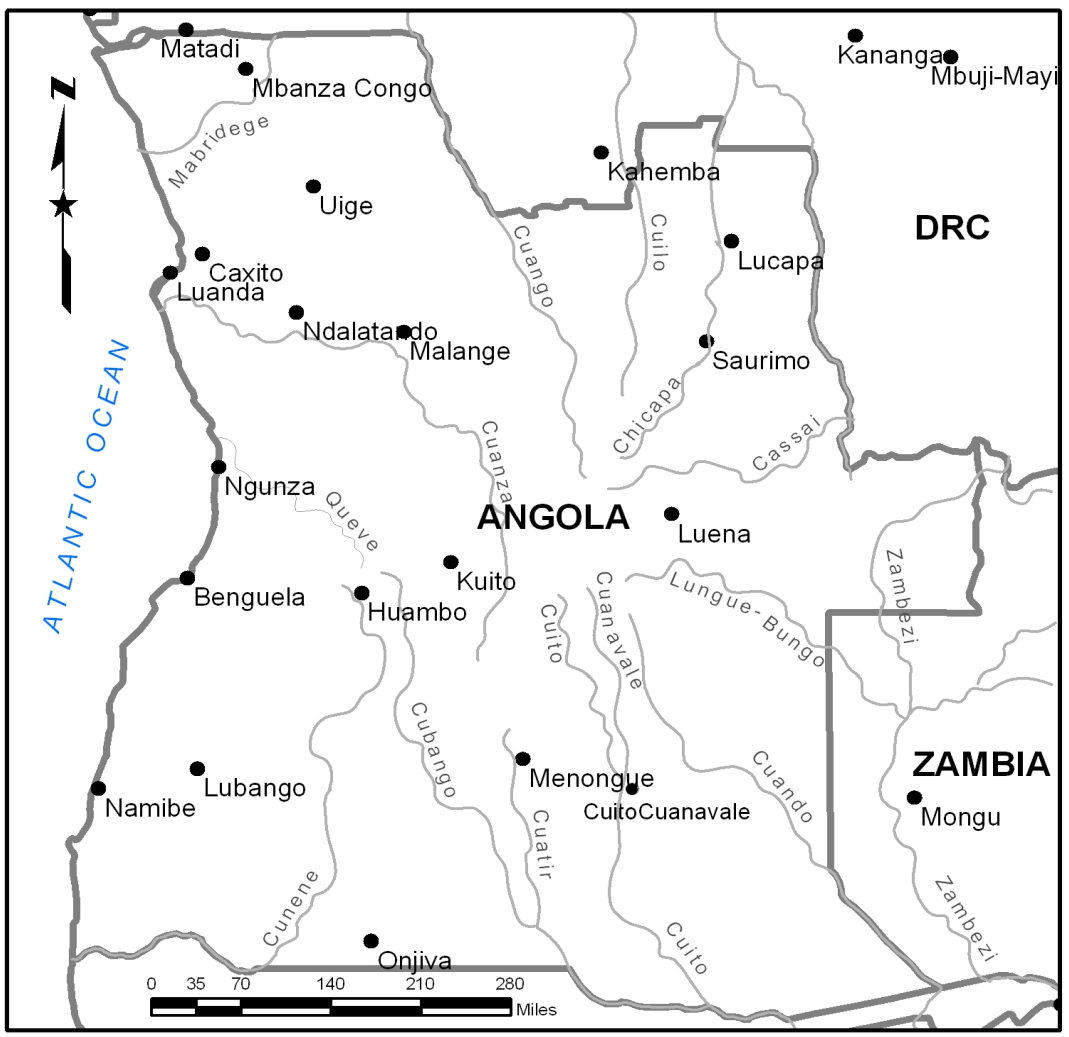

Map 1: Angola ${ }^{1}$

${ }^{1}$ Map through the courtesy of the Military Geography Department, Faculty of Military Science, Stellenbosch University. 
According to Shubin (2008:107), differences existed between the Soviet Union and Cuba, especially in terms of the military strategy in Angola. The Cuban contribution was, however, more important. Cuba trained tens of thousands of Angolan soldiers and acted as advisers in the instruction and combat operations of Angolan troops. The Soviet Union advised the High Command of the Angolan armed forces and provided ample supplies of weapons and equipment to the Angolan armed forces.

From the literature it appears that in 1987, the major role-players had the same perspective of the long-term outcomes of the conflict. Resolution 435 and Cuban troop withdrawal formed part of the vision in one way or the other, although different role players had different views on how this should be accomplished. SWAPO and its allies physically challenged the apartheid regime in Pretoria, including the Soviet Union and the South African regime responded to this challenge.

\section{The Battle for Cuito Cuanavale}

For analytical purposes, the course of the Battle for Cuito Cuanavale can be divided into three stages:

- The Angolan offensive and South African intervention.

- The escalation of the conflict by South Africa and subsequent Cuban escalation; and

- The strategic impasse that paved the way to for peace.

On 1 May 1987, after the Angolan government offensive was confirmed, it was decided by Chief of the South African Defence Force to deploy two liaison teams from the South African Military Intelligence Division east of Cuito Cuanavale to assess the situation together with UNITA (SADF 1988a). Involvement by the SADF was to remain clandestine with the main responsibility of stopping the offensive still resting with UNITA (RSA, House of Assembly 1988). The SADF nevertheless prepared for air and ground attacks on FAPLA while the latter was on the march. On 22 June 1987, the South West African Territory Force (SWATF) was ordered to support UNITA in halting the offensive. Operation MODULAR was to be conducted in escalating phases (SADF 1987). By mid-August 1987, it was clear that the force levels were inadequate if the stated aims were to be achieved (Geldenhuys 1993:167). The FAPLA offensive on the different fronts continued. On 28 August, at Mavinga, the UNITA leader, Jonas Savimbi, admitted that UNITA had no prospect of stopping the offensive on its own, and requested South Africa to increase its aid. He also agreed that UNITA would deploy the Stinger anti-aircraft missiles obtained from the USA to protect the South African artillery. Restrictions on air support by the SA Air Force were also lifted and 61 Mechanised Battalion of the SADF was placed on alert at Oshivello in Namibia. The 
Battalion entered the fray at the beginning of September 1987. By the end of the first week of September 1987, the South Africans assembled a brigade-size force (later called 20 Brigade) to achieve these aims by the end of September 1987 (SADF 1988a).

On 4 September 1987, 20 Brigade received the mission to ensure that the FAPLA/Cuban advance was stopped. Subsequently, the advance of FAPLA's 47 Brigade, attempting to reach Mavinga by moving around the source of the Lomba, was stopped by SADF artillery barrages (Geldenhuys 1993:169). On 12 and 13 September, elements of 59 FAPLA Brigade crossed the Lomba River to join 47 FAPLA Brigade. They withdrew after being driven off by 20 Brigade (Geldenhuys 1993:170).

On 28 and 29 September 1987, the South African State President, the Minister of Defence and the Deputy Minister of Defence visited 20 Brigade Headquarters on the Lomba front where President Botha gave his personal approval for the planning of a more offensive intervention. The aim was to destroy the FAPLA brigades deployed east of the Cuito River, before the start of the rainy season. Botha made it clear that the aim of the new offensive had to be to inflict such a crushing blow on FAPLA that no offensive on their part in 1988 would be possible (RSA 1989:57). Consequently, in the first week of October 1987, heavy fighting took place near the Lomba River. The FAPLA offensive was finally stopped on 3 October 1987 when 47 Brigade was destroyed by mechanised forces of the SADF and UNITA. The remainder of the Angolan forces was then forced back to Cuito Cuanavale (Republic of South Africa 1989:77).

After neutralising 47 Brigade at the Lomba and fighting near the Chambinga River, the SA Army could not immediately pursue the enemy due to insufficient forces at the time. Maintenance of momentum was forfeited as no reserves were available to exploit the favourable situation the SADF enjoyed (RSA 1988a). However, the SADF had completed its mission as FAPLA's offensive capabilities had been neutralised. The SADF, however, could not withdraw and had to ensure that FAPLA did not regroup and resume its offensive. It was jointly decided by the leadership of the SADF and UNITA that the latter had to base its future defence on Cuito Cuanavale, and therefore the SADF decided to exploit and strengthen the Cuito River as an obstacle (Geldenhuys 1993:172).

On 9 November, FAPLA's 16 Brigade, in an effort to force the FAPLA forces to the west of the Cuito River, was attacked with mechanised forces supported by Mirage-F-1 AZs. Most of the brigade escaped but FAPLA lost all their tanks (Heitman 1990:121). During fighting from 9 to 17 November, the last of FAPLA's offensive capabilities were temporarily neutralised. The SADF could neither drive them from the area east of the Cuito River, nor destroy the FAPLA brigades comprehensively and thus allowing these forces to create an adequate defensive position east of the river. FAPLA had only been pushed to the north of the Chambinga River. The morale of some SADF troops 
were low and equipment was failing because of inadequate logistics. FAPLA was deployed over a wide area and dug in over a limited area of good defensive ground and could not be driven out by artillery alone. A subsequent political decision authorised a deliberate attack on the FAPLA positions east of the Cuito River. Since the South African forces consisted of mainly national servicemen whose term of duty was to expire on 15 December, a decision was taken to replace them with new troops from South Africa (Heitman 1990:224).

According to Campbell (1988:12), after the siege of Cuito Cuanavale by the SADF in November 1987, the South African forces in Angola experienced stiff resistance from the forces in Angola and the South African state president had to boost the morale of the troops in person. ${ }^{2}$ According to Crocker (1992:366), this visit prompted the fortification of the Angolan position by Cuba in order to prevent a direct threat to Cuban forces in Angola.

Cuba landed the first 15000 reinforcements and their best pilots on 15 November 1987 in Angola. The best Cuban combat units were selected to respond to the situation. In addition, a group of advisors, officials, and cadres were flown to Cuito Cuanavale. Artillerymen, tank forces, and technicians joined them. This group of about 200 Cubans was later joined by artillery, tank and infantry units to secure Cuito Cuanavale. The Cuban-Angolan strategy was not merely to stop the SADF at Cuito Cuanavale, but also to lure the SADF into concentrating enough forces so that Cuba could advance and attack in south-western Angola. Sufficient forces were gathered to threaten places of strategic importance to South Africa in territory chosen by Cuban and MPLA commanders. The principle was that decisive battles should take place in territory selected by Cuba and that the SADF had to be struck at its weak points, in areas of strategic importance. Cuba preferred a political solution, but if it had no alternative, was willing to strike the South Africans with all its power (Castro 1988:8).

On 25 November 1987, the UN Security Council voted unanimously to condemn the South African intervention, and demanded that South Africa unconditionally withdrew its forces by 20 December. On 5 December, General Geldenhuys announced the withdrawal of South African troops from Angola to be completed by Christmas 1987 (Jaster 1990:19). Although the USA voted for the resolution, it was stated that the US government was seeking a settlement that involved the removal of all foreign forces from the region (USA 1989:29). In the mean time the first three hundred Cuban reinforcements began arriving in Cuito Cuanavale in early December 1987, followed by a Cuban infantry regiment and a tank company from Menongue (Crocker 1992:366).

${ }^{2}$ Campbell is probably referring to the visit by the then President P.W. Botha and his cabinet to Tactical HQ of the SADF north of Mavinga in late November 1987. 
On 10 December, the Angolan government announced that it had authorised Cuba to engage the SADF (Jaster 1990:19).

On 13 December 1987, a new operation, Operation HOOPER, was launched by the SADF. According to the operational instruction for Operation HOOPER, the General Officer Commanding the forces of the SA Army in SWA had to destroy the FAPLA forces east of the Cuito River by 31 December 1987 (Heitman 1990:189). Subsequently, from 14 December onwards, the SADF concentrated on air attacks and artillery bombardments. By 24 December, the bridge over the Cuito had been so weakened by shelling and air attacks that it had to be closed to vehicles. However, the bridge was functioning again by 27 December 1987. On 3 January, it was further damaged by a South African air-delivered "smart bomb" (Heitman 1990:198).

On 2 January 1988, an attempt was made at the Cuito front to drive 21 Brigade from its position by delivering maximum firepower. This second effort failed as well and it became clear that a third deliberate attack would be needed to destroy 21 Brigade (Heitman 1990:197). From 29 December 1987 to 3 January 1988, while the SADF constantly fired its artillery at Cuito Cuanavale, the Cuban High Command decided to redeploy its forces in Menongue to Cuito Cuanavale. The result was a change in the balance of forces, particularly in terms of air superiority, as well as in terms of the antiaircraft defence of Angola (Carrasco \& Gonzales 1988:4).

According to Castro (Barber 1989:40), the number of Cuban troops in Angola was not sufficient to defend a line that was $700 \mathrm{~km}$ long, and in addition to advance through $200 \mathrm{~km}$ of woods from Menongue to Cuito Cuanavale. It was difficult to get supplies to Cuito Cuanavale from Menongue. Therefore, it was imperative to reinforce the troops and apply an adequate concept of operations. The Cuban government therefore decided on reinforcements to prevent both the annihilation of Angolan troops as well as the development of the "complicated situation" that could result for Cuba. Cuba was in no way responsible for the previous errors made by the Soviet Union and FAPLA that led to the situation, but could not allow "a military and political disaster to take place". It was decided to send the most experienced pilots of the Cuban air force to Angola to conduct air strikes from the Menongue air base against South African troops at Cuito Cuanavale. Cuban commanders took charge and quickly ordered the defensive line, comprising 59 Brigade, 25 Brigade and 21 Brigade, to shorten so that it could be covered by artillery positioned west of the Cuito River.

On 4 January, it became known that the Cuban 50 Brigade was deploying to Cunene Province in south-western Angola (Heitman 1990:199). At that stage, SADF units operated east of the Cunene River as far as $10 \mathrm{~km}$ from Cuvelai against SWAPO. Towns like Mupa and Mongua were avoided to prevent contact between the SADF and 
FAPLA. Counter-insurgency operations also continued in Ovamboland on the northern border of the then South West Africa (RSA 1988a).

It was at this point that Castro used his now famous boxing analogy to explain the carefully formulated strategy: Cuito Cuanavale in the east represented the boxer's defensive left fist that blocks the blow, while in the west the powerful right fist had struck, placing the SADF in a perilous position (Gleijesis 2006).

On 13 January 1988, a third South African attack on 21 Brigade was launched. After a successful attack, 4 South African Infantry Battalion and 61 Mechanised Brigade withdrew to the east of the Chambinga high ground. They failed, however, to annihilate 21 Brigade and most of the brigade personnel escaped to the Tumpo triangle to reorganise (Heitman 1990:213).

On 28 January, General Geldenhuys visited Tactical Headquarters where he stated that the South African casualties created some pressure on the SADF in South Africa, but that a degree of understanding of the situation was forthcoming from "Western countries". He also reiterated that FAPLA had to be driven to the west of the Cuito River (Heitman 1990:220).

By then it became clear that the military conflict had the potential to alter the military strategic situation in eastern and south-eastern Angola. FAPLA had not only been unable to defeat UNITA, but FAPLA positions in south-eastern Angola were in danger. The capture of Cuito Cuanavale by the SADF could force the FAPLA line of defence back to Menongue, with the Angolan government losing territory it had taken years to gain. It would have linked SADF operations in Cuando-Cubango Province and Cunene Province and SWAPO targets would have been outflanked from the east and north-east (USA 1987). Negotiations on 28 and 29 January 1988 in Luanda, between Dr Crocker and Angolan representatives, resulted in an agreement by Angola and Cuba about the total withdrawal of Cuban troops in Angola as part of a Southern African peace settlement (USA 1989:40).

On 14 February 1988, the SADF achieved a victory by destroying FAPLA's 59 Brigade and driving 21 Brigade and 25 Brigade back into the Tumpo Triangle. According to Castro (Barber 1989:40), the SADF crashed through the five kilometre gap between 21 Brigade and 59 Brigade encircling 59 Brigade. The SADF could have exploited as far as Cuito to neutralise three entire brigades and 3500 Angolan soldiers. In a counter-attack, Cuba lost seven tanks. The Angolan brigades retreated to the river. They were trapped because the SADF had destroyed the bridge at Cuito Cuanavale. Although most of the forces in Cuito Cuanavale were Angolans, they were no longer a factor in the war, and it was left to the Cubans to secure Cuito Cuanavale. On 25 February 1988, South African forces attacked FAPLA positions south of the Tumpo 
River and at Dala to pin down FAPLA in the area. According to SADF commanders involved, the attack on Tumpo failed because of the tactical ability of the Cubans. Two further attacks on Tumpo (on 29 February and 23 March) again failed because of effective defence by Cuban forces (Heitman 1990:253).

This final battle at Tumpo, where the SADF lost three tanks in a minefield, proved to be detrimental to the morale of the SADF. The troops had fought too many fights and there was no indication of relief. The SADF did not succeed in driving the enemy out of their bunkers on the eastern bank of the Cuito River. The SADF lacked the offensive means and the killer instinct. The SADF suffered more losses of equipment and personnel than usual and had no substantial reserves available to continue the fight. Aircrew members, both in helicopters and fighters, were exhausted by the numerous operations. The offensive was then stopped owing to considerations such as the costeffectiveness of the operation (RSA 1989a). The SADF was also under pressure from President Botha to terminate the intervention because he did not want "another Vietnam". The perception was that the mission had been accomplished (Geldenhuys 1993:177).

On 30 April 1988, a defensive operation, Operation DISPLACE, was launched by the SADF to prevent a FAPLA offensive during 1988. The aim of the operation was to enclose the bridgehead with a minefield to prevent FAPLA from advancing from the east bank of the Cuito River (Heitman 1990:281).

The Battle for Cuito Cuanavale was effectively over. At that stage, the consequences were not clear, but it soon became evident that the use of military force became counter-productive for all role-players involved. The SADF could not capture Cuito Cuanavale and simultaneously fight the Cuban forces in Cunene Province without unacceptable loss of life and high costs. The Soviet Union and Cuba, the sponsors of Angola and SWAPO, agreed with the USA that the military conflict had to end in the interest of broader world peace. It was therefore futile for anybody to continue the war on this level. The time had come to employ the diplomatic and political options towards a peaceful solution, despite the risk of a continued low-scale guerrilla conflict in both Angola and Namibia.

\section{The strategic outcomes of Cuito-Cuanavale}

The outcomes of the military conflict can be described as "a dream come true" for all stakeholders, mostly the regional role-players, including the apartheid government. A scenario unfolded towards the peaceful settlement of disputes in the region, very much in agreement with the expectations of all the major role-players.

Between 7 and 11 November 1989, 670000 Namibians cast their ballots for the election of a Constituent Assembly. SWAPO won more than 57 per cent of the vote, 
enough to win 41 of the 72 seats in the Assembly, but well below the critical two-thirds majority. Even though SWAPO was deprived of a two-thirds majority, other political parties did not get significant Ovambo support either. Almost a quarter of a century of war in Ovamboland and Southern Angola had done nothing but kindle support for SWAPO. Ovambo ethnic and nationalist sentiments won the day for SWAPO. The four northern districts, bordering Angola (Ovambo, Kavango, Kaokoland and the Caprivi) accounted for about 95 per cent of the vote for SWAPO (Esterhuyzen 1990:72)

Analysing the possible strategic implications the independence of Namibia would have for the South African government, the State Security Council of South Africa concluded that the economic dependence of Namibia upon South Africa would be the basis of future bilateral relations. A hostile attitude to the South African government was expected, but it was not foreseen that Namibia would pose a military threat to South Africa, or that the Namibian government would allow its territory to be used for aggression against South Africa (RSA, State Security Council 1989:7-9)

The result of the battle of Cuito Cuanavale gave SWAPO, and others struggling for independence, renewed confidence. The military balance in Southern Africa was changed in favour of liberation and the self-determination of blacks (Campbell 1988:14). The severe economic constraints on South Africa, coupled with its military setback in Angola and the realisation that it could not win the war, tilted the balance in favour of Namibian independence. The Cuban presence on the Namibian border in 1988 meant that, for the first time, South Africa had a military disadvantage with the muchfeared threat of a conventional war in Namibia becoming a possibility. This was to have a decisive influence on negotiations for peace in Angola and independence for Namibia (Dreyer 1988:51). While the negotiations agreed on Cuban troop withdrawal from Angola and relocation of ANC military camps to Uganda, this was no setback compared to the enormity of the strategic gains for liberation movements (Gleijeses 2007).

According to Kasrils (2008:11), irrespective of what side of the battle lines the protagonists served, the closure of the shameful era of colonialism and apartheid in our region, so interlinked with the breakthrough at Cuito Cuanavale, has freed all and opened the way for progressive advancement to the benefit of everybody. Many of those generals and politicians who to this day still stubbornly claim that the SADF was victorious at Cuito Cuanavale, are in fact enjoying favourable business opportunities with their former Angolan adversaries.

An opportunity was created for major peace dividends for South Africa, who was spending billions on defence, nuclear development, arms self-sufficiency and strategic industries. Constructive diplomacy could open doors in Africa and beyond (Crocker 1992:491). The 1988 peace negotiations enabled South Africa to consult with African 
leaders on regional issues of mutual concern. South Africa's leaders initiated a diplomatic and economic outreach that gained them greater participation in African affairs, as well as wider de facto recognition than at any time before (Jaster 1990:64).

Nevertheless, the forces against which the intervention was aimed remained active. Armed hostilities between the MPLA and FAPLA never ceased, and, although UNITA was always in a strong military position, it was defeated decisively in the general elections in 1992. The serious losses suffered by FAPLA and the eventual demobilisation of the forces before the elections in September 1992, as well as the withdrawal of Cuban forces from Angola, left UNITA as a strong destabilising factor in the region. This state of affairs lasted until the death of its leader, Jonas Savimbi, in 2002.

In Namibia, the conditions were far from secure. During the election period in November 1989 and after the independence of Namibia in 1990, a strong contingent of Cuban forces was still present in Angola. Although honouring the stipulations of the settlement, the presence of the troops enabled FAPLA units that would otherwise have been involved in the protection of key points, to become available for a renewed offensive against UNITA during the election period in 1989. Furthermore, the SADF's confinement to base shifted the military balance in favour of SWAPO and created leeway for the People's Liberation Army of Namibia (PLAN) to establish a military presence in Namibia (Velthuizen 1994:115)

For the regime in Pretoria, the outcome of the negotiations had an important consequence in the departure of Cuban forces from Angola in 1990 and 1991. The withdrawal of Cuban forces, removed the only credible conventional military threat to the interests of the South African government. The PLAN was disbanded as a direct consequence of the implementation of UN Resolution 435, leaving only a token force after 1990 in the form of the Namibian Defence Force (NDF).

This new strategic situation relieved the SADF from long-term and costly external commitments outside the borders of South Africa, enabling future South African governments to allocate available resources more realistically and according to new national priorities.

The long-term political solution that resulted from the Battle of Cuito Cuanavale and circumstances surrounding it proved to be durable for South Africa. A diplomatic solution meant that South Africa could perpetuate good relations with neighbouring countries, including Angola and Namibia, through the establishment of healthy economic relations and less emphasis on military force. This new regional atmosphere ensured secure conditions for South Africa to address internal political demands stimulated by the outcome of the elections in Angola and Namibia, without the risk of 
external military interference at a very vulnerable stage. The contribution of the battle to find a peaceful political solution to the conflict in South Africa and an end to apartheid is probably the most important long-term consequence of the battle of Cuito Cuanavale.

\section{Conclusions}

The Battle of Cuito Cuanavale during 1987 and 1988 was one of the final and most significant battles of the Cold War. The battle permanently changed the political and strategic landscape of the Southern African region. The peace negotiations that followed in the wake of this battle led to the withdrawal of the South African military from Angola and Namibia, resulting in the independence of Namibia and a negotiated settlement in South Africa. The outcomes of the military campaigns in Angola paved the way for a series of events that led to the achievement of the political objectives of liberation movements in South Africa, Angola and Namibia, supported by the international community.

These outcomes correlate with the foresight of all the major role-players in the conflict. The apartheid regime foresaw that military involvement in Angola could not continue forever and that Namibia had to become independent. However, peace had to be guaranteed for this to take place.

For the liberation movements of South Africa it was the start of fulfilling a vision of the end of apartheid, a new democratic dispensation in South Africa, and the probability of an end to armed hostilities.

For SWAPO and its allies, the outcomes were exactly as foreseen. Maybe some had expected a more radical transformation towards Marxism and retribution, but most people in Namibia were grateful for a peaceful outcome.

For the major powers involved in the Cold War, it was also an ideal outcome. Peace in Angola and Namibia contributed to a peaceful end to the Cold War. In addition, Cuba, as major military role-player, could now withdraw from a situation that required extreme sacrifice from its people, but one that resulted in Cuba displaying itself as a reliable partner in the context of the developing world.

An important lesson that can be learned from the expectations of long-term outcomes and their alignment with the real outcomes is the value of long-term foresight for strategising in an international context. From the situation as discussed, it is learned that long-term outcomes should be based on an idealistic vision of what is desired. If parties agree to this vision, it serves as continued guidance for actions to ensure the fulfilment of this vision. Diversion away from this vision can only take place through a specific decision, such as when to use military force or when to make peace. A decision of this nature will determine whether the long-term outcome had been 
reached, or not. In the case of Cuito Cuanavale, those involved made many timely and defendable decisions that ensured the ideal of peace in the region.

It is therefore recommended that any foresight of what conditions in South Africa should be twenty years from now be based on a clear vision of peace, and that all roleplayers in the region should maintain all possible instruments to ensure peace. The Battle for Cuito Cuanavale showed the importance of the military as instrument of peace, if implemented wisely with the diplomatic means available. Moreover, if this foresight of peace is combined with the foresight of freedom, the highest universal values are served.

\section{REFERENCES}

African National Congress (ANC). 2008. Statement of the National Executive Committee of the African National Congress on the occasion of the 96th anniversary of the ANC: 8 January 2008. www.anc.org.

Barber, S. 1989. Speech by President Fidel Castro to the Cuban Council of State on 19 July 1989. Defence \& Foreign Affairs, September.

Campbell, K.M. 1988. Southern Africa in Soviet Foreign Policy. Adelphi Papers 227. Winter 1987/88. London: International Institute for Strategic Studies.

Carrasco J. and Gonzales J. 1988. Defeating a Myth: The Message of Cuito Cuanavale. Prisma, 9(88).

Castro, F. 1988. Directly translated speech on Radio Havana on 10 December 1988. The Caribbean, 12 December 1988.

Crocker, C. 1992. High Noon in Southern Africa: Making Peace in a Rough Neighborhood. New York: W.W. Nortan \& Company.

Du Plessis H.D. 1988. Resolusie 435: Agtergrond, Bepalings en Toepassing (MA thesis. Potchefstroom: University of Potchefstroom).

Dreyer, R. 1988. Namibia and Angola: The Search for Independence and Regional Security, 1966-1988. Geneva: Graduate Institute for International Studies.

Esterhuyzen, P. 1990. In Cornwell, R. Leistner, E \& Esterhuyzen P. (Eds.). Namibia 1990: An African Institute Survey. Pretoria: Colorpress. 
Geldenhuys, D. \& Venter, D. 1979. Regional Co-operation in Southern Africa: A Constellation of States? South African Institute of International Affairs Bulletin, December 1979.

Geldenhuys, J. 1993. Dié wat Wen (The Winners). Pretoria: Van Schaik.

Gleijeses, P. 2006. Moscow's Proxy? Cuba and Africa 1975-1988. Journal of Cold War Studies. Vol. 8. No. 2.

Gleijeses, P. 2007. Cuito Cuanavale Revisited. Mail\&Guardian, 11 July.

Heitman, H.R. 1990. War in Angola. Gibraltar: Ashanti.

Jaster, R.S. 1990. The 1988 Peace Accords and the Future of South-Western Africa. Adelphi Papers 253, Autumn.

Kasrils, R. 2008. Historic Turning Point at Cuito Cuanavale. Address by Ronnie Kasrils, Minister for Intelligence Services, Rhodes University, 28 May, Grahamstown.

McFarlane, S.N. and Nel, P. 1989.The Changing Soviet Approach to Regional Conflicts. The Journal for Communist Studies, 5:2.

Republic of South Africa, House of Assembly. 1988. Debates (Hansard). Address by the State President, the Honourable P.W. Botha, 24/8/88, col. 15963-15974.

Republic of South Africa, State Security Council. 1989. Situation Report (106/89 dd 15 December), 1989:7-9.

Shubin, V. 2008. The Hot “Cold War”. The USSR in Southern Africa. London: Pluto Press.

South African Defence Force. 1987. Planning Directive 2/87: WALENE. Unpublished confidential document.

South African Defence Force. 1988a. A Concise History of Operation Modular. War Diary 1986 (WD 1986), Box 40. Pretoria: South African National Defence Force Archives.

South African Defence Force. 1988b. Sektor 10 Jaarverslag 1988, Appendix A: Operational Objectives. War Diary 1988 (WD 1988), Box 39. Pretoria: South African National Defence Force Archives. 
South African Defence Force. 1989a. Lessons Learned During Conventional Operations in the Western Sub-Theatre. Unpublished confidential document.

United States of America, United States Army Intelligence and Threat Analysis Centre (USAITAC). 1987. Cuba and Angola: The View from 1987. Miami, 10-14 December 1987.

United States of America, Department of State. 1989. The US and Angola, 1974-88: A Chronology. Department of State Bulletin, February.

Velthuizen, A.G. 1994. The Use of Military Force for Political Ends: The Case of South Africa in South-Western Africa. MA thesis. Pretoria: University of South Africa. 